\title{
Государственный язык \\ в медиапространстве: \\ проблемы культуры речи ${ }^{1}$
}

Елена Вартанова

(C) Вартанова Елена Леонидовна член-корреспондент РАО, профессор, доктор филологических наук, декан факультета журналистики МГУ имени М.В. Ломоносова, заведующая кафедрой теории и экономики СМИ факультета журналистики МГУ имени М.В. Ломоносова, главный редактор журнала «МедиаАльманах» (г. Москва, Россия), eva@smi.msu.ru
За последние 20 лет медиа, из которых мы получаем актуальную общественно-политическую информацию о мире, значительно расширились. Наряду с прессой и телерадиовещанием Интернет, социальные сети, поисковые системы, мессенджеры заполнили коммуникационную среду современного человека. Интернетом в России пользуется 75,4\% взрослых россиян (16+, по данным FGK), а среднее время пребывания в медиапространстве в стране уже превышает девять часов в будние дни и десять часов в выходные (16+, по данным Deloitte). Выросло поколение молодых людей, которых называют «цифровой молодежью», «цифровым поколением», поскольку онлайн-медиа стали для них не только основной средой общения и получения информации, но и новой средой социализации и даже обитания.

Медиапространство, бесспорно, стало главным полигоном, где происходят процессы трансформации государственного языка. Это касается и изменения значения слов, и их написания, и образования новых лексических единиц. Нужно отметить, что именно в медиаречи мы можем найти не только грамотное, но и умелое использование речи - языковую игру (придание слову разнообразных оттенков, привлечение внимания аудитории изобразитель- 
но-выразительными средствами и т.д.). В общем, есть и ошибки, есть и достоинства.

Для журналистов русский язык - это в первую очередь профессиональный инструментарий, но одновременно это и наше общее культурное достояние. Аудитория прессы, телевидения, радио всегда рассматривала язык, с помощью которого она получает информацию, как ориентир, образец владения речью. Но эта образцовость сейчас в значительной мере утрачена. Современные медиа скорее отражают сложные процессы, происходящие с языком в обществе, но, к сожалению, не могут рассматриваться как авторитетный источник языковой нормы.

Основные ошибки современной медиаречи в значительной степени связаны с нестабильностью государственных и общественных институтов в 1990 гг. Падение речевой культуры в целом в стране проявилось прежде всего в жаргонизации речи; просторечия и нецензурная лексика, которые раньше всегда были на периферии речевой практики и, конечно, немыслимы на страницах газет, в теле- и радиоэфире, многими журналистами стали восприниматься как вполне допустимые и даже стали элементом некоей бравады: дескать, я свободен и ничем не ограничен в форме самовыражения.

Именно просторечная лексика, а не иноязычные заимствования (хотя журналисты безудержно используют в своих текстах «хайпы», «луки», «лайфхаки», «фэшн-блогеров» и т.п., путают «кураж» и «фураж», «гранты» и «гранды»; под угрозой и традиционное для русского языка интонирование, когда в электронных СМИ журналисты начинают говорить с интонацией, характерной для английского языка) является сейчас главной угрозой культуре русской речи.

Под влиянием медиаречи меняется значения слов, когда они входят в медиалексику с одним значением, а затем приобре- тают дополнительные смыслы. Часто это происходит с терминами из научной сферы, значение которых, наверно, было непонятно использующим их журналистам, но привлекло звучанием.

Снижение речевой культуры сказывается и в частом нарушении лингвоэтики. Например, «Дни.ру» «величает себя» «влиятельной российской интернет-газетой» и тем не менее позволяет себе дать заголовок «Морщинистую Стриженову поперли с Первого канала» (06.10.2018). В целом можно констатировать активизацию языка вражды, особенно в социальных сетях.

Культура речи, точнее ее снижение, связана с размыванием норм словоупотребления: с одной стороны, часто встречаются отклонения от норм, воспринимаемые в обществе как допустимые (дОговор, договорА); а с другой стороны, нет четкой договоренности, к каким словарям следует обращаться в поиске этих норм². Кстати, это создает проблемы в процессе обучения для средней и высшей школы.

Для того чтобы верно судить о состоянии современного русского языка, нужно не просто фиксировать его употребление: это уже делает Национальный корпус русского языка. Необходим анализ особенностей русской речи, причем именно с позиций культуры ее использования в нашем общественном пространстве, которое определяется состоянием медиаречи в коммуникационном поле. Именно оно затрагивает всех - и ученых, и политиков, и деятелей культуры и образования - собственно говоря, каждого из нас.

Забота о родном языке, сохранение его богатства, стремление к правильности и образности речи - это цели языковой политики государства. Положительным примером такой политики уже на протяжении десятилетий является Франция, где включение новых заимствований в язык - результат долгого, всесторонне осмысленного процесса. 
Развитие нормативной базы языка, профессиональный анализ того, что публикуется в СМИ, забота о культуре медиаречи - эти важные задачи могли бы взять на себя академические и образовательные учреждения, имеющие опыт изучения разных сфер медиа - журналистики, рекламы, связей с общественностью, политических и экономических коммуникаций, массовой культуры. Такой постоянный мониторинг мог бы приобрести форму регулярных национальных аналитических докладов о состоянии государственного языка в медиасфере. Президентский Совет по русскому языку вполне мог бы выступить инициатором подготовки такого доклада, обратившись к РАН, столичным и региональным вузам, изучающим вопросы культуры медиаречи. Впоследствии такую практику можно было бы распространить и на другие области речевой деятельности общества - научную речь, официальноделовую коммуникацию и т.д.

Аналитический доклад о состоянии государственного языка в медиапространстве, несомненно, будет интересен как представителям законодательной и исполнительной власти, профессиональному медиасообществу - журналистам, авторам СМИ, медиаменеджерам, профессиональным ассоциациям, представителям сферы среднего и высшего образования, сообществам интернет-блогеров и социальных сетей, так и широкой общественности.

Уверена, такое внимание к состояние государственного языка в сфере медиа найдет особое понимание в регионах, где местные газеты и телевидение по-прежнему пользуются большим влиянием, а социальные сети уже стали средством общения и образования.

В контексте идеи медиаграмотности культурно-речевые явления могут быть важным компонентом образовательного процесса - прежде всего в средней школе. И молодые люди должны критически оценивать не только содержание того, что появляется в Интернете, но и его форму, насколько она соответствует национальной традиции использования речи.

\section{Примечания}

${ }^{1}$ Выступление на российско-французском лингвострановедческом семинаре «Языковая политика во Франции и в России: проблемы и перспективы», проходившем 11-12 декабря 2019 г. в Москве на факультете журналистики МГУ имени М.В. Ломоносова. Семинар проводится под эгидой российско-французского форума гражданских обществ «Трианонский диалог» в сотрудничестве с Федеральным агентством по печати и массовым коммуникациям (Роспечать), Министерством просвещения России и Министерством культуры Франции.

2 Перечень словарей, которыми пользуются редакции:

Академический орфографический словарь. Научно-информационный «Орфографический академический ресурс АКАДЕМОС» Ин-та рус. яз. им. В. В. Виноградова РАН. Режим доступа: http://orfo.ruslang.ru/

Большой толковый словарь русского языка / гл. ред. С.А. Кузнецов. Первое издание. СПб..: Норинт, 1998.

Борунова С.Н., Воронцова В.Л., Еськова Н.А. Орфоэпический словарь русского языка: произношение, ударение, грамматические формы / под ред. Р.И. Аванесова. 4-е изд., стер. М.: Рус. яз., 1988. 
Граудина Л.К., Ицкович В.А., Катлинская Л.П. Грамматическая правильность русской речи. Стилистический словарь вариантов. М.: Наука, 2001.

Ожегов С.И., Шведова Н.Ю. Толковый словарь русского языка. Первое издание. М.: Азъ, 1992.

Розенталь Д.Э. Управление в русском языке. М.: ООО «Издательский дом «ОНИКС 21 век»»: ООО «Издательство «Мир и Образование»», 2005.

Розенталь Д.Э., Теленкова М.А. Словарь трудностей русского языка. 3-е изд. М.: Айрис-Пресс, 2003. 